\title{
DISTANCE LEARNING OF MATLAB PROGRAMMING
}

\author{
PERUTKA, K[arel]
}

\begin{abstract}
The paper deals with the course which is a part of distance learning and it is used by students of combined curriculum. The basics of MATLAB programming and SIMULINK is the contents of the course. The course is organized as a set of video clips and covers the whole taugh subject. Audio tracks in the files are available in Czech language only. This course is the first video course about $M A T L A B$ programming in Czech language which is available for free on the web pages of the MathWorks company. The course was developed from my lectures' notes under my supervision. This paper shortly describes the contents of the course and practical experience with the usage of this course.
\end{abstract}

Key words: curriculum, distance learning, MATLAB

\section{INTRODUCTION}

The education is the mile stone of the mankind rise. During last years, the sharp rise of information technology, the Internet and access to information appears. In these days, nobody doubts about continuous education. Nice paper about important role of engineers in the society was published by Katalinic (Katalinic, 2010). According to this paper, the continuously increasing knowledge of the civilization is connected with technology and it has important role in the globalization of the world.

The right to education, which is a common right of human rights, contributed and still contributes to the sharp rise of the knowledge and technology of the global society. There was published a paper which briefly summarizes the history of the right to education and several aspects of education (Saramet et al., 2010). Everyone has the right to education according to the Universal Declaration of Human Rights. The education is compulsory and has to be free of charge, at least the basic education. The European Convention on Human Rights implements the right to education which is valid in Europe.

But education is only one step to obtain the appropriate job. Students should ask themselves what they want to do after graduation. Also for that purpose, universities ask their students about their expectations. For example, there was realized the inquiry about the similar topic at Politehnica University of Bucharest (Nicolae, 2010). Author of the mentioned paper also compares how graduates of several faculties are successful in acquiring their job. The questionnaire was interesting part of the paper. It deals with the access to the funds of the European Union and planning the business simulation. It was proven that the knowledge of getting the important and necessary information is at least as important as the special skills or professional qualification.

Distance learning has important role in education system. It is helpful both for students and teachers. Teachers usually have to spend more time in classes during the teaching lessons repeating the same topic to several classes in one week. Some students understand everything during teaching lesson at first but some only a part. For such students it is useful to choose their own studying rate which distance learning offers. Several subjects can be taught by distance learning, for example programming. Programming of Pascal language as a part distant learning process was also published 3 years ago (Pardanjac\&Radosav, 2008). The paper includes the results in the point of research and opinion of the students who used it. It mentions that distance learning increases the students' motivation and decrease the studying time.

Distance learning can be enlarged by the software tools which interactively help to understand the students the actual studying task. For example, there was created the software tool simulating the pneumatic systems (Bagimov at al., 2008). The purpose of this software was to create a distance tool to cover the most important part of the learning process.

The remainder of the paper is organized as follows. The description the created video course is given firstly. The personal experience with this tool is given after. This is followed by the plans for the future development of the tool and conclusion.

\section{DESCRIPTION OF MATLAB VIDEO-COURSE}

The created MATLAB video-course covers the basics of MATLAB and SIMULINK programming and it is divided into 14 lessons according to the lengths of the semester, see figure 1. The first lesson deals with the description of the MATLAB Desktop environment including menus, panels, windows and dialogs. Next lesson describes variables and data types, how to create variables and the suggested rules for their creation. There are examples of data types used for numbers and strings as well as examples of cell arrays and structures.

Chapter 3 works with vectors and matrices. It shows how to create them plus the functions mostly used with matrices and vectors. Another lesson provides the basics of work with complex numbers and polynomials including the definition of complex number and functions for complex numbers and polynomials.

Chapter 5 deals with the description of trigonometric functions, exponential functions, logarithmic functions and functions which are used for number rounding. There is shown the syntax of each of the named functions together with the sample code. Next chapter is oriented on strings, for example creating strings, functions used for strings comparison, linking strings together.

Chapter 7 shows examples of relation and logical operators. Moreover, the syntax of condition and cycles is provided, i.e. if, while, for, switch.The following chapter presents the sample creation of simple script and simple M-function in MATLAB editor.

Chapter 9 deals with graphs. There are presented functions for several basic types of graphs, how to create graph and how to edit parameters and properties in the graph. Not only 2D graphics is presented, but creation of $3 \mathrm{D}$ graphs is given as well. Next chapter includes the symbolic functions description. There is shown the symbolic computation of derivation, integral, limit, Laplace transformation and symboli solution of algebraic and differencial equations. 
Chapter 11 introduces the functions for work with files such as returning the file name and path, opening the files, reading data form files and writing them in the files, closing the files. Creating GUIs (Graphical User Interfaces) or dialogs is important part of the programming. There is a tool in MATLAB to easy the design and programming of GUIs. Description of this tool together with the sample dialog creation is presented in Chapter 12 which is the last lesson about MATLAB.

Next two lessons describe the bases of work in SIMULINK environment. The first lesson provides the introduction of SIMULINK showing the commonly used blocks and scheme or model creation, saving data to variable in the MATLAB Workspace, creating new subsystems and blocks with the block masking and creation of new input dialog for newly created block, see figure 2 .

The last lesson of the MATLAB-SIMULINK video course, chapter 14 , presents the solution of differential equations and their systems using block scheme in SIMULINK. The last part of the lesson shows the options and results obtained from LTI viewer, Control System Toolbox.

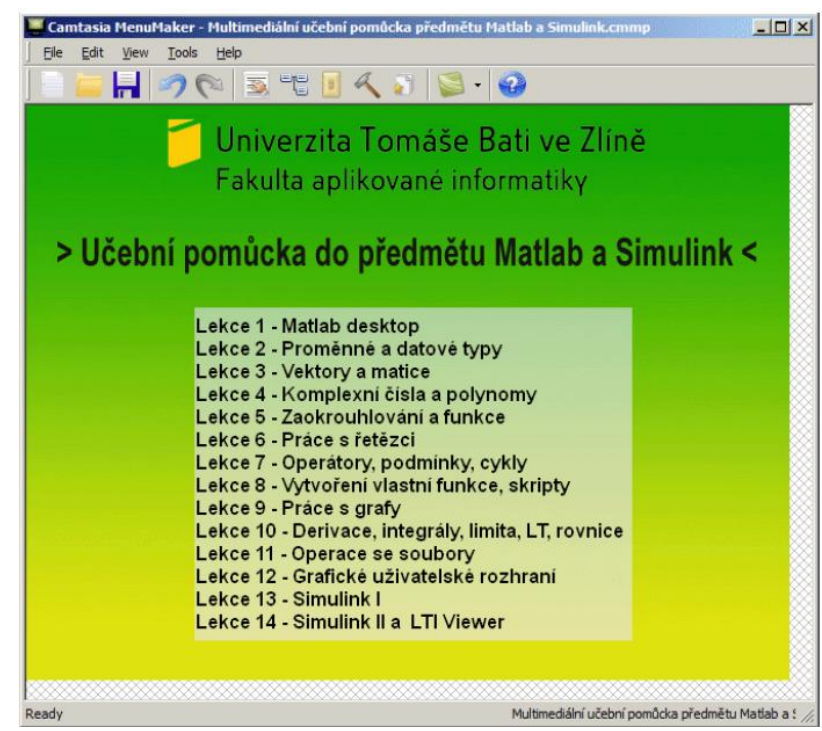

Fig. 1. Main screen of MATLAB video course

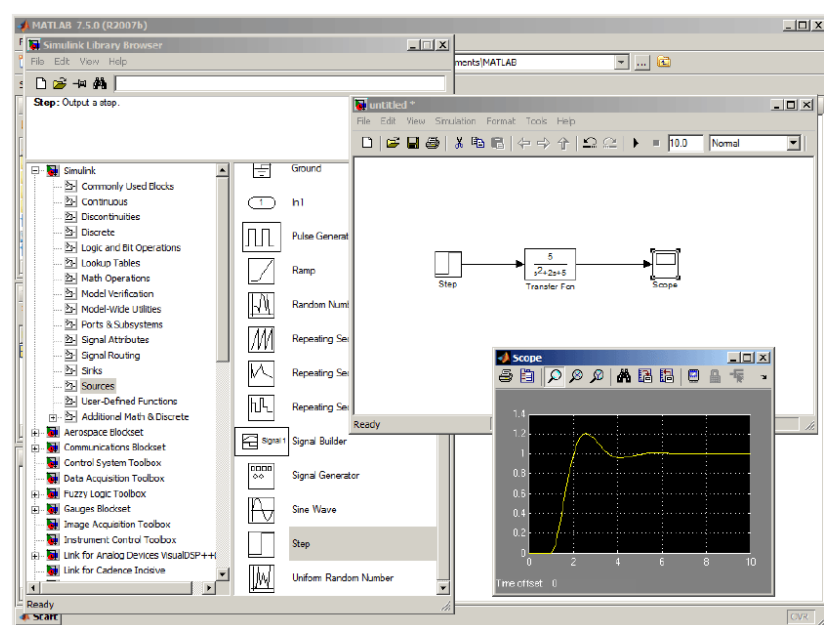

Fig. 2. Sample screen of MATLAB video course

\section{PRACTICAL EXPERIENCE}

The teaching in time before the MATLAB video-course was created was organized in the following way. Students wrote down notes about each MATLAB function which was described, its syntax and examples. Usage of this teaching method caused that students knew only the pure core of programming.

The created MATLAB video course, which was placed on the webpages of the software producer, helps to improve the quality of education and allows us to increase the amount of studied topics in the area of control theory and telecommunications.

The video course is free of charge for the students of the long-life curriculum during their first lesson. They can watch and pause each lesson or chapter according to their free time. The video course is valued by students because of several advantages which it provides. Students do not need to concentrate on writing down everything and they can re-watch the chosen part as many times as it is necessary. After two weeks they know the bases of MATLAB programming and they are prepared to practice the advanced lessons. Their content is directly connected to the subjects of the curricullum that use MATLAB for simulation.

\section{CONCLUSION}

In this paper, there was presented the MATLAB video course in Czech language, which helps students understand and practice the bases of MATLAB programming without their presence at school. There is provided information about practical experience and advantage of this course during teaching. Future work is oriented in two ways. It would be useful to enlarge the course by new audio tracks for several languages, at least English, French, Spanish and German. Plus it would be useful to create the extentension of the video course or new lessons from the area of the software implementation, for example from the area of control theory or telecommunications.

\section{ACKNOWLEDGEMENTS}

The work was supported by MSM7088352101 grant.

\section{REFERENCES}

Bagimov, I.; Konobritskiy D. \& Kramar, V. (2008). Distance learning of programming language Pascal, Proceedings of the $19^{\text {th }}$ International DAAAM Symposium, ISSN 17269679, ISBN 978-3-901509-68-1, Katalinic, B. (Ed.), pp. 5354, DAAAM International Vienna, Austria, EU

Katalinic, B. (2010). Engineers for knowledge based society, Proceedings of the $21^{\text {st }}$ International DAAAM Symposium, Volume 21, No. 1, ISSN 1726-9679, ISBN 978-3-90150973-5, Katalinic, B. (Ed.), DAAAM International Vienna, Austria, EU

Nicolae, S. (2010). The school-to-work transition in the perception of students from Politehnica University of Bucharest, Proceedings of the $21^{\text {st }}$ International DAAAM Symposium, Volume 21, No. 1, ISSN 1726-9679, ISBN 978-3-901509-73-5, Katalinic, B. (Ed.), pp. 699-700, DAAAM International Vienna, Austria, EU

Pardanjac, M. \& Radosav, D. (2008). Distance learning of programming language Pascal, Proceedings of the $19^{\text {th }}$ International DAAAM Symposium, ISSN 1726-9679, ISBN 978-3-901509-68-1, Katalinic, B. (Ed.), pp. 1021-1022, DAAAM International Vienna, Austria, EU

Saramet, O.; Manu, R.; Toma-Bianov, A. \& Gabor, D.O. (2010). Aspects regarding the right to education, Proceedings of the $21^{\text {st }}$ International DAAAM Symposium, Volume 21, No. 1, ISSN 1726-9679, ISBN 978-3-90150973-5, Katalinic, B. (Ed.), pp. 697-698, DAAAM International Vienna, Austria, EU

*** (2010) http://www.mathworks.com - The MathWorks, MATLAB File Exchange, MATLAB video tutorial registered by Radim Michalek, Accessed on: 2011-04-05 